\title{
Autoidentyfikacje współczesnej młodzieży \\ - przyczynek do dyskusji na temat: Młodzież, czyli kto?
}

KEY WORDS

young people, identity, autoidentification

\begin{abstract}
Myszka Lucyna, Autoidentyfikacje współczesnej młodzieży - przyczynek do dyskusji na temat: Młodzież, czyli kto? [Self-Identifications of Contemporary Youth - A Contribution Towards The Debate on the Topic: Youth, Who Is That?]. Kultura - Społeczeństwo - Edukacja nr 2 (4) 2013, Poznań 2013, pp. 141-163, Adam Mickiewicz University Press. ISBN 978-83-232-2703-3. ISSN 2300-0422

Modern youth, forced to live in complicated and unpredictable reality, faces the task of building its own identity and finding its own auto identification. This article is an analysis of this subject, based on research conducted by the author. It tries to find an aswer to questions like "who is modern youth", "how does it present itself and shape its own self image" and "how does modern youth percieve the surrounding reality".
\end{abstract}

Współczesna rzeczywistość określana jest jako ambiwalentna, nieprzewidywalna, zróżnicowana, wielokulturowa, jednolita, dynamiczna. Można więc stwierdzić, że postrzega się ją jako pełną sprzeczności i przeciwieństw, ponieważ jedyną jej stałą właściwością jest ciągła zmiana. Najczęściej obdarza sięją mianem ponowoczesności, którą postrzega się jako konsekwencję i następstwo nowoczesności (Dziamski, 1995: 147). O ile za atrybut minionych czasów uznawało się działanie zgodnie z pewnymi regułami, które wprowadzały porządek oraz umożliwiały przewidywanie mających nastąpić wydarzeń, o tyle współczesność całkowicie zrywa z tą zasadą, ponieważ okazała się dysfunkcjonalna i ukierunkowuje się na podążanie za teraźniejszością nastawioną na niełatwą do przewidzenia przyszłość. Za prekursorów tak rozumianej ponowoczesności uważa się Jeana Françoisa Lyotarda, Jacquesa Derridę, Michela Foucaulta i Jeana Baudrillarda. Właściwością łączącą poglądy owych badaczy jest fakt, że przypisywali jej podobne cechy, z których kluczową stanowiła permanentna zmiana. 
Po bliższym przeanalizowaniu kategorii, jaką stanowi ponowoczesność, okazuje się, że skomplikowanym zadaniem jest wyznaczenie okresu, w którym rozpoczyna się jej geneza. Z pewnością można go uplasować na początku XX wieku wraz z powstaniem traktatu Study of History Arnolda Toynbee’a, który używał takiego określenia $\mathrm{w}$ odniesieniu do współczesności. $\mathrm{Z}$ kolei inni badacze jej narodziny kojarzą z okresem zanikania „wielkiej narracji”, która pozwalała wyznaczyć aktualne położenie w dziejach ludzkości i przewidzieć przyszłość (Lyotard, 1997). Co ciekawsze, Barry Smart, uważa ją za coś minionego, pozostawiającego ślad w istniejącej kulturze (Smart, 1998: 12). W związku powyższymi rozważaniami pojawia się pytanie: jaka właściwie jest obecna rzeczywistość i co będzie jej następstwem? Stanowi kategorię nie tylko trudną do jednoznacznego zdefiniowania i nadania konkretnych ram czasowych, ale również jest przestrzenią, w której trudno żyć. Wieloznaczny i heterogeniczny świat zmusza do nieustannej autokreacji. Z jednej strony oferuje bardzo dużo możliwości oraz szans do wykorzystania, jednak z drugiej - egzystujące w niej jednostki pozostawia bez żadnego wsparcia, pokładając zaufanie wyłącznie w ich zdolnościach adaptacyjnych. Okazuje się, że bardzo ciężko odnaleźć się w rzeczywistości pozbawionej aksjomatyzacji oraz pewnych stałych wartości, a co za tym idzie - funkcjonować bez planów na przyszłość, dlatego warto przyjrzeć się kondycji współczesnego człowieka oraz radzenia sobie w świecie permanentnej zmiany (patrz: Cybal-Michalska, 2006).

Jednostka ludzka autotelicznie stanowi niezgłębioną tajemnicę, której działania są nieprzewidywalne, co sprawia, że zamierzenie zdiagnozowania jej stanu w obecnych czasach staje się jeszcze bardziej skomplikowane. Współczesnego człowieka można określać zarówno mianem homo viator (Marcel, 1960), który nieustannie podąża za swoim celem, jak i homo ludens (Huizinga, 1967) - ponieważ większość swojego życia poświęca zabawie przybierającej postać gry, czy homo faber (Pico della Mirandola, 2010) - przyzwyczajonego do ciężkiej pracy i produktywności. Świadczy to o mnogości możliwych do obrania strategii zapewniających funkcjonalność we współczesnym świecie. Okazuje się jednak, że jednostka przyjmuje różne oblicza w zależności od sytuacji, w której się znajduje. Charakteryzuje ją „niespójność, niekonsekwencja postępowania, fragmentaryzacją i epizodyczność rozmaitych sfer aktywności” (Bauman, 1993: 7). Każdy podmiot działań posiada niezliczoną ilość masek, które może zmieniać, łączyć ze sobą lub przekształcać. Ponowoczesny człowiek musi posiadać umiejętność poruszania się pomiędzy różnymi systemami znaczeń (Fiut, 2004: 62). Taka sytuacja wymaga od niego zdolności szybkiego uczenia się i podejmowania trafnych decyzji, ponieważ każda pomyłka grozi porażką. Znaczącą rolę w tej kwestii odgrywa poczucie wolności, które utwierdza jednostkę w przekonaniu, że samodzielnie może decydować o swoim losie (Bauman, 1993: 30). Okazuje się jednak, że wbrew pozorom, uwikłana jest w machinę konsumpcyjną, która pochłania dosłownie wszystko: 
czas, przestrzeń, przedmioty oraz innych ludzi, natomiast ona dokonuje tylko wyboru spośród prezentowanego przez nią asortymentu (Marciniak, 2011: 36-41). Taka sytuacja, w pewnym sensie, jest wynikiem samodzielnych wyborów człowieka, ponieważ to właśnie on konstruował istniejącą przestrzeń, z drugiej zaś strony jest w niej zakotwiczony do tego stopnia, że stracił możliwość panowania nad jej rozwojem, dlatego też decyduje się na adaptację do panujących warunków.

Niniejsze rozważania skłaniają do refleksji poświęconej kondycji współczesnej młodzieży, która jako grupa oscylująca pomiędzy dzieciństwem a dorosłością jest najbardziej podatna na wpływy otaczającej rzeczywistości. Z jednej strony sama zmienia świat i wprowadza w nim swoje udoskonalenia, stawiając opór zaistniałym czynnikom, z drugiej zaś, będąc bardzo podatna na oddziaływania otoczenia, pozwala na swobodny rozwój ponowoczesności. Dlatego też młode jednostki stają się obiektem zainteresowania wielu naukowców. Badacze reprezentujący różne dziedziny, takie jak pedagogika, psychologia, socjologia, biologia, prowadzą rozważania na temat ich tożsamości, stylu życia, aktualnie uznawanych wartości i preferencji. Kwestia poznania strategii stosowanych przez młodzież, które umożliwiają jej przetrwanie w zmiennej i nieprzewidywalnej rzeczywistości, jest bardzo ważna, jednak równie istotne są dociekania terminologiczne oscylujące wokół kategorii pojęciowej młodzieży, co nie pozostaje bez znaczenia dla jakości poznania naukowego zjawisk związanych z młodzieńczością.

Według niektórych źródeł pojęcie młodzieży pojawiło się dopiero pod koniec XVIII wieku, wraz z powstawaniem społeczeństwa mieszczańskiego (Oleniacz, 2005: 14). Wiązało się to $\mathrm{z}$ powszechną migracją ludzi z terenów wiejskich do miast, a co za tym idzie, z nabywaniem nowych sposobów życia. Wcześniej kategoria młodzieży istniała tylko w zamożniejszych sferach, ponieważ potomstwo ubogich ludzi musiało pracować już od najmłodszych lat i często postrzegano je jako miniaturki osób dorosłych. Do młodych osób nie przywiązywano większej wagi. Starano się nie wchodzić z nimi w głębsze relacje emocjonalne, ponieważ ze względu na zły stan warunków bytowych, nierzadko umierały (Bartnicka, 1994: 81-130). Inna dokumentacja donosi, że za przyczynę wyodrębnienia się kategorii młodości można uznać rozwój edukacji i powszechne zwrócenie uwagi przez ludzi na konieczność kształcenia potomstwa dla zapewnienia dogodniejszego położenia rodziny (Oleniacz, 2005: 14).

Według innych źródeł termin 'młodość' pojawił się dopiero w XIX wieku jako rezultat przeobrażeń związanych z rewolucją przemysłową (Bąk, 2008: 16) oraz zmian w kulturze i spopularyzowania współczesnego systemu biurokratycznego, który zakładał prowadzenie dokładnej ewidencji urodzeń i zgonów (Sińczuch, 2002: 13). Natomiast powstanie i ugruntowanie się obecnego rozumienia młodzieńczości miało miejsce dopiero na początku wieku XX (Siwko, 2006: 34). Zaczęły wtedy powstawać pierwsze prace naukowe opisujące okres dojrzewania. 
Między innymi w 1904 roku została wydana naukowa rozprawa na temat adolescencji napisana przez Stanleya Halla, uważanego za twórcę psychologii rozwojowej (Psychologia dziecka, 1995: 32). Określił ją mianem czasu „burzy i naporu” ze względu na gwałtowność dokonujących się w niej zmian (Brich, Malim, 2002: 121). W późniejszym okresie, szczególnie po II wojnie światowej, badania na temat młodzieży rozwinęły się z powodu gwałtownie rosnącej liczby młodych członków społeczeństwa.

Młodzież stanowi kategorię bardzo złożoną i trudną do jednoznacznego zidentyfikowania. Prawidłowość ta wynika $\mathrm{z}$ faktu, że można ją różnie interpretować w zależności od kontekstu, którym jest rozpatrywana. Na tle biologicznym młodzież łączona jest $\mathrm{z}$ różnego rodzaju zmianami zachodzącymi w jej organizmie, związanymi z dorastaniem. Z kolei, w obszarze psychologicznym, młodzież badana jest $z$ punktu dojrzewania psychicznego, zmian intelektualnych, emocjonalnych i skłonności do przyjmowania buntowniczej postawy wobec otoczenia.

Kategoria społeczna nawiązuje do postrzegania młodzieży, jako pewnej grupy społecznej zobligowanej do nabycia umiejętności pełnego i odpowiedzialnego uczestnictwa w życiu danej zbiorowości. Samuel N. Eisenstadt (Eisenstadt, 1996: s. 112-117), który jest przedstawicielem ujęcia funkcjonalnego, dostrzega u młodych ludzi pewne predyspozycje, które pozwalają im na pełnienie wielu funkcji. Dla niego młodzież to jednostki, które z racji wieku pozostają $\mathrm{w}$ stanie przejściowym między procesem socjalizacji pierwotnej i wtórnej. W związku z tym, że nie są wystarczająco przygotowane do samodzielnego funkcjonowania, tworzą grupy rówieśnicze, które zaspokajają ich potrzeby przynależności i bezpieczeństwa oraz wyposażają $\mathrm{w}$ wiedzę charakterystyczną dla osób dorosłych, zapewniając $\mathrm{w}$ ten sposób utrzymanie równowagi w społeczeństwie.

Podejście kulturowe rozpatruje młodych ludzi, jako grupę posiadającą kulturę o cechach odmiennych od tej, w której funkcjonują osoby dorosłe. W tym obszarze można umieścić teorię transmisji wartości kulturowych stworzoną przez Margaret Mead (Mead, 1978: 25-147), w myśl której młodzież dostosowuje swoje zachowanie do specyfiki kultury panującej, ucząc się jej i przekazując następnym pokoleniom. Wyróżnia trzy rodzaje kultur: postfiguratywną, w której normy i wzorce przyjmowane przez jednostki są ściśle określone i nie zmieniają się wraz z czasem, konfiguratywną, gdzie młodzi ludzie mają możliwość autokreacji, korzystając z rad i doświadczenia swoich rodziców, oraz prefiguratywną, nastawioną na nieznaną i trudną do przewidzenia przyszłość, w której to młode osoby uczą starsze, jak egzystować w istniejącej rzeczywistości. Młodzież można rozpatrywać również z perspektywy pokoleniowej. Zgodnie z teorią Karla Mannheima (Mannheim, 1996: 84) o pokoleniu mówi się dopiero, kiedy określoną grupę osób łączą wspólne przeżycia i doświadczenia, a nie tylko fakt urodzenia się w tym samym czasie. 
W klasycznym rozumieniu zaproponowanym przez Helmuta Schelskiego (Schelski, 1996: 104-106) pojęcie 'młodzież określa stan przejściowy pomiędzy dzieciństwem a dorosłością. Z kolei Wincenty Okoń, przypisuje jej określone ramy czasowe, które w ontogenezie jednostki przypadają na „17.-18. rok życia i trwają do 22.-25. roku życia” (Okoń, 2007: 456). Zgodnie z powyższymi rozważaniami można stwierdzić, że młodzież stanowią jednostki w określonym wieku, przeżywające różnorodne zmiany zarówno na tle biologicznym, jak i psychologicznym oraz będące w zobowiązaniu do wykonania określonych zadań, których pozytywne rozwiązanie pozwoli na zaliczenie ich do grona ludzi dorosłych.

Bardzo ważnym zadaniem dla tego okresu życia staje się skonstruowanie własnej tożsamości. Dlatego też warto zadać sobie pytanie: czym tożsamość właściwie jest? Stanowi pojęcie występujące na gruncie różnych nauk, począwszy od matematyki, filozofii, a na psychologii, socjologii i pedagogice skończywszy. Termin ten pochodzi od łacińskiego słowa idem, które oznacza identyczność i ciągłość (Golka, 2006: 9). Zajmowali się nim również starożytni filozofowie. Do ich grona z pewnością możemy zaliczyć Arystotelesa, dla którego tożsamość oznaczała relację zachodzącą pomiędzy dwoma przedmiotami. Do człowieka pojęcie to zaczęto odnosić w XIX wieku i dopiero wtedy nabrało ono znaczenia funkcjonującego obecnie. Za kreatora takiego obrotu spraw należy uznać Williama Jamesa. Wyróżniał on „Ja empiryczne”, czyli poznawane, oznaczające wszelkie własności i cechy, które człowiek przypisuje sam sobie oraz „Ja poznające” odnoszące się do aktywności jednostki, jej zmian i czuwające nad jej jednością jako osoby (James, 2002: 119-122). Natomiast do spopularyzowania zainteresowania terminem „tożsamość" i powszechnego jego używania przyczynił się Erik Erikson. Prowadząc swoje rozważania na polu psychoanalizy, spowodował późniejsze przeniesienie tego zagadnienia na grunt innych teorii psychologicznych. Pojmował on tożsamość jako świadome poczucie swojej osoby, zachowanie ciągłości i realizowanie własnego planu rozwojowego, który powinien być zgodny z normami uznawanymi przez grupę funkcjonowania jednostki (Erikson, 2004: 98).

Tożsamość pozwala jednostce na udzielenie odpowiedzi na pytanie „kim jestem?", pozwala poczuć swoją wyjątkowość i odrębność oraz jednocześnie zaspokaja potrzebę przynależności do określonej grupy społecznej (Trzebińska, 1992: 195). Składają się więc na nią nie tylko wyrażenia na temat własnej osoby, ale również informacje o tym, co o jednostce myślą inni. W związku z tym, że stanowi pewien rdzeń osobowości człowieka, a jej prawidłowe ukształtowanie jest niezwykle ważne dla dojrzewającej jednostki - zadania tego może podjąć się dopiero wówczas, gdy posiada zdolność krytycznego myślenia na temat siebie i otoczenia, ponieważ zobowiązany jest do wykształcenia realnego konstruktu, oscylującego pomiędzy własnymi możliwościami, a pragnieniami, dążeniami i fantazjami (Oleś, 2011: 139). Niestety, takie przedsięwzięcie wymaga pewnych 
umiejętności i wiedzy. Jest bardzo trudne ze względu na warunki stwarzane przez współczesną rzeczywistość, ponieważ ciężko konstruować jednoznaczną wizję siebie w świecie pozbawionym stabilnych znaczeń i autorytetów. Dlatego też tożsamość przybiera postać elastyczną, która zmienia się w zależności od zaistniałych warunków.

Współcześnie młodzież odgrywa bardzo ważną rolę w życiu społecznym. Tworzy swoją własną kulturę, prezentuje osobliwe style zachowań, a ponadto bardzo wyraźnie zaznacza swoją obecność na wszystkich płaszczyznach funkcjonowania człowieka. W związku z czym wielu ludzi dąży do tego, by jak najdłużej pozostać jednostką młodą, poprzez dbanie o swój wygląd, kondycję fizyczną i przyjmując nowoczesny sposób myślenia. Spopularyzowanie znaczenia młodzieńczości zawdzięcza się także w dużej mierze społeczeństwom zachodnim i postępującym procesom globalizacyjnym (Sińczuch, 2002: 14-15), w wyniku których młodzież staje się głównym konsumentem oferowanych przez nich dóbr kultury.

Specyfika ambiwalentnej i pełnej sprzeczności współczesności może wywoływać w młodzieży poczucie zagubienia, wyobcowania, niepewności. „Zamiast trwałych i stabilnych hierarchii oraz wyraźnych linii ewolucyjnych mamy nieustanne starcia sprzecznych opinii i sądów (...) oraz bitwy prowadzące w najlepszym razie do stworzenia nowych hierarchii równie kruchych, nietrwałych i tymczasowych jak poprzednie" (Bauman, 2011: 243) Takie czynniki z pewnością nie zapewniają stałości, która stanowi podwalinę poczucia bezpieczeństwa. Sytuacja ta może utrudniać młodym jednostkom dokonywania wyborów, których lista wynikająca z ich okresu rozwojowego, jest stosunkowo długa. W związku z czym młodzi ludzie coraz częściej odczuwają strach, niezdecydowanie oraz nieustannie poszukują swojej drogi życiowej. Z pewnością tego typu okoliczności mają odzwierciedlenie w kreowaniu tożsamości i odnajdywaniu własnych identyfikacji. Młodzież przeżywająca problemy z odnalezieniem godnych do naśladowania autorytetów, stabilnych znaczeń i systemów wartości, opracowuje własne strategie umożliwiające jej przetrwanie.

Autorka niniejszego artykułu przebadała autoidentyfikacje młodzieży w dobie ponowoczesności. Za główny pracy obrała nie tylko poznanie przedmiotu i obszarów identyfikacji jednostek, ale również starano się wzbudzić w młodych ludziach refleksje na temat swojej własnej osoby. Posłużyła się metodą sondażu diagnostycznego, techniką ankiety oraz narzędziem kwestionariusza ankiety. Problemami badawczymi uczyniła kwestie związane z przyjmowanymi przez młodzież autoidentyfikacjami w kontekście odpowiedzi na pytania: „kim jestem?”, „kim chcę być?”, „kim mogę być?”, „kim jestem skoro różnię się od innych?”'.

${ }^{1}$ Przytoczone rozważania, stanowią fragment dociekań naukowych i eksploracji badawczych poczynionych przez autorkę w pracy magisterskiej pt. Autoidentyfikacje młodzieży w dobie ponowoczesności napisanej pod kierunkiem prof. dr hab. Agnieszki Cybal-Michalskiej. 
Badania zostały przeprowadzone na przełomie grudnia 2012 roku i stycznia 2013 roku na terenie województwa wielkopolskiego oraz kujawsko-pomorskiego w pięciu wybranych szkołach ponadgimnazjalnych, wyselekcjonowanych ze względu na swoją lokalizację i dostępność, ponieważ nie wszyscy dyrektorzy szkół wyrażali zgodę na przeprowadzenie eksploracji badawczych²

Łącznie badaniami objęto 173 uczniów uczęszczających do ostatnich klas szkół ponadgimnazjalych. Były to osoby w wieku od 18 do 20 lat. Młodszym wiekiem charakteryzowali się przyszli absolwenci szkół zawodowych i liceów ogólnokształcących, natomiast starszym - uczniowie techników ze względu na przewidywany dłuższy okres pobytu w instytucjach kształcenia. Uwagę na tę grupę wychowanków zwrócono ze względu na osiągnięcie przez nich wieku, w którym powinni odznaczać się relatywnie ustabilizowaną osobowością, a co za tym idzie, dojrzałością psychiczną i społeczną. Poza tym klasy absolwenckie stoją przed koniecznością wyboru swojej dalszej drogi edukacyjno-zawodowej, dlatego też, refleksja nad własną osobą może stać się dla nich właściwym impulsem do podjęcia racjonalnych decyzji.

Grupa badanych była bardzo zróżnicowana. Łącznie ankietę wypełniły 173 osoby, kobiety stanowiły 42,8\%, natomiast płeć męską reprezentowało 57,2\% ogółu ankietowanych. W tym można wyróżnić: $22,5 \%$ uczniów szkół zawodowych, 49,2\% uczniów techników i 28,3\% osób uczęszczających do liceów. Natomiast, jeśli chodzi o rozkład badanych względem miejsca zamieszkania, okazuje się, że $58,4 \%$ respondentów pochodzi z terenów wiejskich, 7,5\% zamieszkuje miasta nieprzekraczające 50 tysięcy mieszkańców, 5,8\% miasta, których liczba mieszkańców plasuje się w przedziale $50-100$ tysięcy, zaś $28,3 \%$ pochodzi z wielkich aglomeracji miejskich liczących powyżej 100 tysięcy mieszkańców.

Przeprowadzone badania ukazują bardzo interesujący obraz współczesnych nastolatków. Okazuje się, że dobrze radzą sobie z funkcjonowaniem w wielowymiarowej rzeczywistości podlegającej nieustającej zmianie, ponieważ pomimo licznych przeszkód potrafią odnaleźć swoje własne ,ja” i skonstruować względnie stabilny obraz siebie. Obecne tożsamości przyjmują postać bardzo elastyczny i uwarunkowany przez kontekst, co gwarantuje im rację bytu w świecie ponowoczesnym. Unikają stałych cech, ponieważ nie znajdują one zastosowania

${ }^{2}$ Dwie szkoły znajdują się na terenach wiejskich, natomiast pozostałe trzy - w Poznaniu. Szkoły, w których przeprowadzono badania, były zróżnicowane ze względu na specyfikę kształcenia oraz właściwości środowiska lokalnego. Szkoły wiejskie charakteryzują się bowiem innymi parametrami niż szkoły miejskie. Najczęściej wyróżniają się infrastrukturą o mniejszej kubaturze, liczą mniej uczniów, z których większość, chcąc uczęszczać na zajęcia, jest zmuszona pokonywać odległość większą niż 10 kilometrów. Z kolei jej otoczenie dostarcza mniej rozrywek i znamionuje się względnym spokojem. Natomiast młodzież ucząca się w szkołach miejskich zazwyczaj korzysta z usług publicznych środków transportu lub chodzi do niej piechotą, chcąc uczestniczyć w zajęciach. Ponadto dostosowuje się do innych warunków nauczania, związanych z bogatą ofertą edukacji pozaszkolnej. 
w ambiwalentnej rzeczywistości (Bauman, 2000: 143). Ich trwałą właściwością jest możliwość dostosowania się do panujących warunków. Co więcej, prawidłowość ta staje się niezbędna we współczesności, ponieważ przetrwa w niej tylko ten, kto posiada zdolność szybkiego adaptowania się do zaistniałych sytuacji.

Wyniki badań pokazują, że młodzież, mimo że ocenia świat przede wszystkim w kategoriach negatywnych (aż 70\% skojarzeń dotyczących współczesności zakwalifikowano jako niepozytywne), odnajduje w nim swoje miejsce i tworzy względnie dojrzałe identyfikacje. Oczywiście, profil tożsamościowy ukształtowany przez współczesną młodzież odbiega od tego, z jakim identyfikowały się wcześniejsze pokolenia, jednak jego istotną cechą jest fakt, że bazuje na pewnych stałych wartościach, jakie stanowi przynależność do gatunku ludzkiego czy płeć. Zjawisko takie można zinterpretować jako ogromny sukces młodych ludzi, którzy pomimo istniejącego kryzysu gospodarczego, ekonomicznego, mentalnościowego i społecznego - potrafią odnaleźć swoje miejsce w ambiwalentnej i nieprzewidywanej rzeczywistości.

Profil stworzony przez adolescentów dotyka zarówno dziedziny tożsamości osobistej, związanej z własnymi wyobrażeniami na swój temat i subiektywnym wartościowaniem siebie, jak i tożsamości społecznej - formułowanej w odniesieniu swojej osoby do innych ludzi oraz postrzeganiu jej w relacjach z nimi (Brzezińska, 2007: 239-241). Ponadto często jego poszczególne właściwości określają na podstawie różnych funkcji, jakie $\mathrm{w}$ ich obrębie pełnią lub zamierzają pełnić w społecznościach swojego egzystowania. Na pierwszy plan wysuwają mającą się dopiero ukształtować w swojej pełnej postaci - tożsamość zawodową, która wyraźnie uwidacznia się w przyszłościowych aspiracjach młodzieży. Świadczy o tym fakt, że na pytanie: „Kim chcę być?” aż 60,1\% respondentów odpowiada, podając konkretny zawód, jaki w przyszłości chcieliby wykonywać. Mniejsze znaczenie ma dla nich rozwinięcie u siebie wybranej cechy charakteru $(11,6 \%)$ czy osiągnięcie określonej pozycji zawodowej (9,3\%). Wyniki takie świadczą o tym, że młodzież ma świadomość znaczenia aktywności zawodowej, która stanowi nie tylko źródło dochodu, ale także często wpływa na ukształtowanie osobowości jednostki. Ponadto, osiągnięcie określonej pozycji zawodowej we współczesnym świecie zapewnia prestiż i wyznacza ścieżkę rozwoju. Co więcej, okazuje się, że rozwój ten należy objąć opieką i wyprofilować jak najwcześniej³.

Wzór, z którym identyfikują się adolescenci, charakteryzuje się wysokim poziomem złożoności i wielowymiarowości. Jego centralne miejsce zajmuje „bycie człowiekiem" (50,7\% respondentów podaje taką odpowiedź w pierwszym skojarzeniu na pytanie: „Kim jestem?”). Okazuje się, że utożsamianie się z gatunkiem ludzkim ma dla młodzieży istotne znaczenie. Pozwala im na odkrycie nie tylko

${ }^{3}$ Patrz: m. in. koncepcja E. Supera, J. Hollanda, A. Roe. 
swoich rdzennych przymiotów, ale również stanowi stały punkt odniesienia. Część badanych podkreśla nawet, że jest to właściwość, która towarzyszy im od momentu urodzenia i pozostanie niezmienna aż do ich śmierci. Bardzo ważną rolę odgrywa również utożsamianie się ze swoją płcią $(17,1 \%)$, posiadane przymioty charakteru $(9,2 \%)$ oraz odgrywanie określonych ról społecznych (4,6\%). Rola oraz związane $\mathrm{z}$ nią powinności w pewien sposób kształtują zachowanie jednostki. Wynikające z niej obowiązki pochłaniają większą część dnia i wymagają realizacji w myśl aprobowanej metody. Podobna sytuacja zachodzi w przypadku płci, która także warunkuje pewne cechy człowieka, sposób ubierania się, zachowania, a co więcej - właściwości biologiczne. Bardziej osobistą kategorię stanowi usposobienie jednostki, które w dużej mierze uzależnione jest od jego indywidualnych preferencji dotyczących sposobu bycia i wartości uznanych za znaczące. Dlatego też staje się ono głównym obszarem troski współczesnych adolescentów $(26,6 \%$ badanych uznaje swój charakter za priorytetowy wśród wymienionych skojarzeń dotyczących siebie). Osobowość jest sferą jednostki, która pozwala na ukierunkowanie swoich działań w myśl przyjętego planu. Młodzież zdaje sobie sprawę z tego, że zdecydowanie bardziej kalkuluje się inwestowanie w swój własny charakter, który podlega większym modyfikacjom, niż w organizm, który z czasem zacznie odmawiać posłuszeństwa. Taki układ wartości młodego pokolenia świadczy o przewadze kategorii „być" nad „mieć”.

Niestety, młodzi ludzie przejawiają zanik płaszczyzn identyfikacji, które były bardzo istotne dla wcześniejszych pokoleń, takich jak tożsamość religijna $(6,4 \%$ respondentów uznaje ją za znaczącą wśród pierwszych pięciu skojarzeń), lokalna $(7,5 \%)$ i narodowa (16,8\%). Z jednej strony, zjawisko takie uwarunkowane jest wymogami współczesnej rzeczywistości związanej z kreowaniem się społeczeństwa globalnego (Bauman, 2000: 71-77), z drugiej zaś wynika $\mathrm{z}$ dążenia człowieka do wolności (Bauman, 1996: 12-14) i wyrwania się z granic myślenia narzuconych przez wymienione przymioty. Sytuacja taka przyczynia się do wykształcania wśród młodych ludzi „ponowoczesnych wzorców osobowości” (Z. Bauman) oraz cech charakterystycznych dla „globalnego nastolatka” (Z. Melosik). Co ciekawsze okazuje się, że chłopcy mają bardziej ugruntowaną tożsamość narodową niż dziewczęta $(5,1 \%$ w odniesieniu do $1,4 \%)$. W tej sferze wyróżniają się także uczniowie szkół zawodowych, którzy częściej niż pozostali deklarują, że są Polakami. Przyczyna takiego stanu rzeczy może tkwić w pewnym archetypie mężczyzny, który czuł się zobowiązany do identyfikowania się z własnym krajem, w związku z czym częściej oscylował wokół pewnych wartości patriotycznych.

Niepokojem napawa niskie poczucie własnego ,ja”, związanego z „byciem sobą” (tylko 4,0\% badanych wskazało ten rodzaj identyfikacji wśród pierwszych pięciu skojarzeń dotyczących swojej osoby) oraz malejące znaczenie uważania siebie za osobę wyjątkową (5,2\%), pomimo że człowiek współczesny odznacza się wysokim 
poziomem indywidualizmu, który daje mu poczucie nadnormalności (Znaniecki, 2001: 268) i sprawia, że odnosi wrażenie bycia kimś niepowtarzanym. Badana młodzież zdaje się tracić tę właściwość. Sytuację taką można uznać za wskaźnik wysokiego stopnia jej zagubienia i niepewności w obecnej rzeczywistości. Nieustanne zmiany i szybkie tempo życia przyczyniają się do poczucia wyobcowania związanego z koniecznością ciągłego określania siebie. „Bycie sobą”, umiejętność odnajdywania się w każdej sytuacji, poczucie sensu i ciągłości siebie nawet w momentach kryzysowych, stanowi kluczową kwestię w egzystencji człowieka. Dlatego też bardzo istotne staje się podjęcie działań zmierzających do uświadomienia młodym ludziom posiadania tej właściwości. Być może cecha ta jest dla nich tak oczywista, że nie zwracają na nią uwagi. Podobna sytuacja ma miejsce w przypadku potrzeb, ponieważ gdy zostają zaspokojone te podstawowe, dążymy do realizacji tych wyższego rzędu.

Prawdopodobnie specyfika współczesności zorientowanej na rozwój gospodarczy i czynnik ekonomiczny sprawia, że adolescenci głównego obszaru swoich aspiracji dopatrują się w płaszczyźnie związanej z własną aktywnością zawodową (odpowiedzi 41,6\% badanych na pytanie: „Kim mogę być?” mieszczą się w obszarze preferencji zawodowych). Zwracają uwage na jej dwa aspekty: związek z kierunkiem kształcenia i zainteresowaniami oraz możliwość osiągnięcia niezależności ekonomicznej i satysfakcji finansowej. Świadomość tego, że obranie właściwej ścieżki zawodowej może wywrzeć znaczący wpływ no losy jednostki i jej umiejscowienie w strukturze społecznej, jest niezwykle istotna. Poprzez przyjęcie takiej postawy młodzież pokazuje, że bardzo wcześnie rozpoczyna refleksję nad swoją przyszłością. Co ciekawsze, niekoniecznie łączy przyszłość zawodową z poziomem i jakością zdobywanej wiedzy czy podejmowanymi działaniami edukacyjnymi (tylko 3,5\% respondentów na pytanie: „Kim chcę być?” wspomina o swoich planach związanych z dalszym kształceniem). Z jednej strony osiągnięcie określonej pozycji przypisuje własnej pracy i wysiłkowi, z drugiej zaś czynnikowi szczęścia. Zdecydowanie rzadziej przedmiotem swoich marzeń mianują szczęśliwe życie rodzinne $(2,9 \%)$ i pracę nad swoim charakterem $(11,6 \%)$. Nawet w przypadku dążenia do realizacji planów życiowych $(4,6 \%)$ często łączą je ze zgromadzeniem dużego majątku lub zdobyciem sławy. Należy jednak zauważyć, że strefa identyfikacji rodzinnej nie jest dla młodych ludzi obca. Co prawda, nieczęsto myślą oni o założeniu swojej własnej rodziny (co prawdopodobnie wynika $\mathrm{z}$ ich stosunkowo młodego wieku), jednak wspominają o funkcjach, jakie pełnią w swoich aktualnych domostwach.

Warto zwrócić uwagę na fakt, że pojawiające się w kwestionariuszu ankiety pytanie: „Kim chcę być?” w pewnym sensie jest związane z płaszczyzną „ja idealnego" - wszystkich wyobrażeń dotyczących jednostki zarówno w sytuacji obecnej jak i w jej przyszłego oblicza. Sfera ta często przybiera postać nierealną lub trudną 
do osiągnięcia. Kategoria „Ja idealnego” została wprowadzona przez Karen Horney. Zakładała ona, że wyidealizowany obraz siebie tworzy się bez udziału świadomości - proces taki stanowi następstwo niezaspokojonych potrzeb. W swoich wyobrażeniach jednostka prezentuje osobę doskonałą, w wyniku czego uzyskuje „poczucie własnego znaczenia i wyższości nad innymi” (Horney, 2001: 17). Natomiast pytanie: „Kim mogę być?” wiąże się z obszarem „Ja realnego”, które uwzględnia aktualny stan człowieka oraz warunki, w których się znajduje, by wykreować swój obraz w przyszłości oparty na zracjonalizowanych aspiracjach. Okazuje się, że obie wizje siebie, stworzone przez nastolatków, są bardzo zbliżone do siebie, co więcej są możliwe do spełnienia.

Adolescenci, prezentując swoje autoidentyfikacje, mieszczące się w obszarze własnych możliwości, z jednej strony skupiają się na celach pozostających w strefie racjonalnych i dających się zrealizować dążeń, które często są zaniżane w stosunku faktycznych ich predyspozycji, z drugiej zaś strony wyróżniają się wysokim stopniem poczucia własnej sterowności, przyczyniającym się do wiary w zdolność osiągania wszelkich aspiracji, wyrażającej się w stwierdzeniu: „Mogę być każdym, kim tylko zechcę". Zjawisko takie wskazuje na złożoność i wieloaspektowość ludzkiej tożsamości, co wyjaśnia tendencję do konstruowania swojego niespójnego wizerunku.

Aspiracje młodych ludzi można rozpatrywać również w rozmaitych kategoriach, pozwalających na odniesienie ich do orientacji temporalnej. Okazuje się, że deklarowane preferencje pozwalają na umieszczenie się zarówno w najbliższej, jak i odległej perspektywie czasowej. W pierwszej z nich znajdowałyby się dążenia zawiązane z edukacją oraz przyszłym zawodem w przypadku młodzieży, która planuje zakończyć karierę oświatową na obecnym etapie. Natomiast w drugiej mogłyby mieścić się pozostałe przemyślenia związane z życiem rodzinnym, charakterem czy pasjami z tego względu, że ich osiągnięcie, czy też rozwijanie, może zająć kilka lat lub nawet całe życie. Najważniejszym spostrzeżeniem wydaje się być jednak fakt, że młodzież główną szansę na udane życie i osiągnięcie pożądanego stanu upatruje przede wszystkim w sferze zawodowej. Prawdopodobnie spowodowane jest to obecnym wymogiem powszechnej aktywności zawodowej, która ułatwia pozyskanie kapitału niezbędnego do osiągnięcia samodzielności i niezależności, stanowiącej marzenie wielu młodych ludzi.

Zgodnie z klasyfikacją Jürgena Habermasa (Habermas, 2000) młodzież konstruuje swoje „ja” w odniesieniu do trzech kategorii: fizykalnej, związanej z pewnymi zewnętrznymi cechami wyglądu oraz podstawowymi określeniami dotyczącymi człowieka, symbolicznego określenia pełnionej roli społecznej oraz indywidualistycznej, której zadanie polega na podkreślaniu wyjątkowości jednostki i cech wyróżniających go spośród innych. Wyniki badań dowodzą, że częstość występowania identyfikacji wśród respondentów zależy od sfery, której dotyczy. 
W związku z czym w kontekście odpowiedzi na pytanie „kim jestem?” najczęściej pojawiające się identyfikacje są związane z obszarem symbolicznym, wyrażane poprzez podawanie określeń dotyczących roli społecznej, rodzinnej, orientacji narodowej, zawodowej, religijnej czy lokalnej. W drugiej kolejności podawane przez respondentów skojarzenia dotyczą sfery indywidualistycznej, plasują się w niej takie kategorie, jak cecha charakteru czy zainteresowania. Najrzadziej zaś występują identyfikacje fizykalne. Taka prawidłowość może być spowodowana faktem, że refleksje dojrzewającego człowieka na temat własnej osoby mają często głębszy wyraz w odróżnieniu od płaszczyzny fizycznej. Co ciekawsze okazuje się, że odpowiedzi udzielane zarówno na pytanie „kim chcę być?”, jak i „kim mogę być?” dotyczą głównie dwóch sfer: symbolicznej i indywidualistycznej. W tym przypadku pierwsza z nich bardziej odnosi się do płaszczyzny zawodowej i związanych z nią planów, rzadziej zaś pojawiają się tutaj aspiracje rodzinne lub związane z innymi obszarami egzystencji. Druga natomiast oscyluje wokół pracy nad własnym charakterem czy rozwojem pasji. W ten sposób młodzi ludzie prezentują świadomość tego, że identyfikacje fizykalne ulegają mniejszym zmianom niż pozostałe $\mathrm{z}$ wymienionych oraz $\mathrm{w}$ mniejszym stopniu są poddawane sterowności z perspektywy jednostki. Poza tym istotniejsza jest dla nich praca nad własną pozycją czy usposobieniem niż cechami organicznymi.

W kontekście analizy kondycji współczesnego nastolatka warto zwrócić uwagę na obszar identyfikacji wskazujących na umiejętność dostrzegania różnic pomiędzy sobą a innymi. Dojrzewanie jest okresem, w którym człowiek powinien posiadać zdolność do decentralizacji i relatywnego myślenia. Wyniki badań ukazują, że młodzi ludzie różnią się pod względem przyjmowanej postawy życiowej i uznawanej cechy. Okazuje się, że młodzież stanowi grupę bardzo zdeterminowaną, gotową na wytrwałe dążenie do swoich celów. Świadczy o tym fakt, że jedną z kluczowych wartości jest dla niej sukces związany z chęcią odnoszenia zwycięstwa (32,9\% respondentów uznaje go za cechę najbardziej pasującą do swojej osoby). Za cenę jego realizacji pozostaje w gotowości do walki i podejmowania kolejnych wyzwań $(42,8 \%)$. Ponadto młodzi ludzie, doskonale radzą sobie w ponowoczesnych warunkach i dostrzegają u siebie umiejętność adaptowania się do nich (tą prawidłowość wybiera 23,7\% badanych). Odzwierciedleniem tej właściwości staje się ruch i nieustanna zmiana, które są nie tylko główną cechą przestrzeni ich funkcjonowania, ale także ich własnego życia (taką postawę życiową deklaruje 43,4\% badanych). Poddają się ciągłej, bezkresnej wędrówce (Bauman, 2005: 209), gotowi na różnorodne niespodzianki, które nie zawsze mają charakter pozytywny.

Młodzież potrafi także być bardzo tolerancyjna (57,9\% badanych zdecydowanie opowiada się za prezentowaniem tej cechy), co wyraża się głównie w zatracaniu przez nią zdolności do krytycyzmu (za tą cechą opowiada się tylko 5,2\%). Poza tym, nie lubi zbytnio pozostawać w centrum uwagi i wyróżniać się spośród 
innych, jednak postawa taka nie zmierza w kierunku całkowitej anonimowości. Prawdopodobnie adolescenci cieszą się z towarzystwa swoich przyjaciół i najbliższej rodziny, jednak gorzej czują się, przebywając wśród wielkiego tłumu. Przeważnie starają się „być sobą" i nie dążą do udawania kogoś, kim nie są $(64,7 \%$ respondentów deklaruje, że nie udaje kogoś, kim nie jest). W związku z czym swój charakter otaczają nie tylko największą opieką i wytrwałą pracą, ale także uznają go za główny czynnik wyróżniający ich spośród innych osób.

Warto zwrócić również uwagę na obszary różnic pomiędzy respondentami wynikające $z$ analizy otrzymanych wyników ze względu na zmienne takie jak płeć, rodzaj uczęszczanej szkoły czy miejsce zamieszkania. Okazuje się, że chłopcy prezentują się jako jednostki nastawione na realizację zadań związanych z rozwojem własnych pasji i zdobyciem określonego zawodu, z którym często wiążą doświadczenie awansu społecznego oraz osiągnięcie wymarzonej pozycji. Ponadto wyróżniają się częstym przyjmowaniem postawy lekkoducha traktującego swoje życie jako nieustanne wakacje. Skłonność taka nie przeszkadza im jednak w chęci odniesienia sukcesu, który wiąże się z wysokim poziomem determinacji i wytrwałym dążeniem do celu. Poza tym ich poziom poczucia wyjątkowości wydaje się być zdecydowanie wyższy niż u płci przeciwnej, ponieważ częściej niż dziewczęta uważają, że od pozostałych osób różnią się wszystkimi właściwościami, jakie posiadają. Przedstawiają siebie jako osoby bardzo elastyczne, dostosowujące się do panujących warunków, co przejawia się również w umiejętności szybkiego podejmowania decyzji. Ich optymistyczne spojrzenie na świat wyraża się nie tylko w samodzielnych deklaracjach, ale także w stworzeniu bogatego zbioru pozytywnych skojarzeń na temat współczesności, reprezentowanych przez takie cechy jak: nowoczesna, zmieniająca się, szybka, ciekawa.

Dziewczęta z kolei intensywniej identyfikują się ze swoją płcią i pełnionymi funkcjami rodzinnymi, a także troszczą się o rozwój swojego charakteru zgodnie z pożądanym kierunkiem. Dążenie do osiągnięcia jak najlepszego usposobienia dowodzone zostaje poprzez fakt czynienia z niego obszaru funkcjonowania, który najbardziej przyczynia się do wyróżniania ich spośród innych osób, podobnie zresztą, jak przyjmowane zasady i normy. Co ciekawsze, przejawiają tendencję do toczenia walki o własną pozycję, która związana jest z ponoszeniem ryzyka, co wymaga od nich nie tylko gotowości ponoszenia strat, ale również ciągłego skupienia i koncentracji na własnych działaniach. Skłonność ta potwierdzana jest poprzez deklarowanie posiadania dużej ilości energii do podejmowania wyzwań. Ich chęć poznawania świata jest tak silna, że najbardziej spośród wszystkich cech, jakie można przypisać współczesności, to możliwość realizowania ciekawości i giętkości poznawczej.

Uczniowie technikum identyfikują się przede wszystkim z pełnionymi funkcjami społecznymi i rodzinnymi, z własną płcią oraz właściwością, jaką stanowi „bycie 
człowiekiem", czyli przynależność do gatunku ludzkiego. Można więc stwierdzić, że podstawę ich tożsamości tworzą podstawowe obszary funkcjonowania człowieka. Ponadto prezentują wysoki poziom orientacji temporalnej, związanej z własną przyszłością zawodową i chęcią odniesienia sukcesu życiowego, co interpretuje się jako nastawienie na przedsiębiorczość i inwestowanie dużych pokładów energii i działań w osiągnięcie określonej pozycji na rynku pracy. Postawa taka wyraża się również $\mathrm{w}$ intensywnym zmierzaniu do realizowania wyznaczonych sobie celów życiowych.

Plany i dążenia życiowe uczniów szkół zawodowych przede wszystkim wiążą się ze zdobyciem zawodu, którego wybór często jest uwarunkowany przez realizowany profil kształcenia. Ta grupa badanych osób prezentuje się jako bardzo aktywna lub przynajmniej tkwiąca w takim przekonaniu. Deklaruje wrażenie pozostawania w nieustannym ruchu, wynikającego $\mathrm{z}$ wykonywania różnorodnych czynności. Za główną strategię funkcjonowania w ponowoczesności obiera adaptację oraz ukierunkowanie na sukces, a także anonimowość, co w pewnym sensie pozostaje sprzeczne z często podkreślaną przez nich chęcią stanowienia głównego obiektu uwagi. Tendencja do prezentowania sprzecznych postaw w tej kwestii wynika prawdopodobnie z uwarunkowań sytuacyjnych, w zależności od których przejawiają odmienne zachowania. Prezentują się również jako grupa chcąca nabywać nowe dobra, co wskazuje na orientację konsumpcyjną. Interesującym spostrzeżeniem jest fakt, że za cechę najczęściej wyróżniającą ich spośród innych osób uznają własny charakter.

Najważniejszym spostrzeżeniem dotyczącym licealistów wydaje się być fakt, że tworzą oni grupę najbardziej zróżnicowaną pod względem prezentowanych identyfikacji. Prezentują nie tylko urozmaicone skojarzenia na swój temat i współczesnej rzeczywistości, ale również podają bogate uzasadnienia udzielanych odpowiedzi, które świadczą o głębokim i wnikliwym analizowaniu własnej tożsamości, a w związku z czym właściwość, z którą identyfikują się najczęściej i w najwyższym stopniu stanowi posiadany przez nich charakter. Przedmiotem swojej refleksji czynią również zainteresowania, czyli własne pasje związane z rozwojem i intensywną pracą. W najniższym stopniu spośród pozostałych uczniów swoje plany przyszłościowe łączą z orientacją zawodową. Prawdopodobnie spowodowane jest to tym, że większość absolwentów liceów kontynuuje edukację w innych placówkach oświatowych, dlatego też proces krystalizacji tego typu planów następuje w późniejszym czasie. Wynikiem takich tendencji są częstsze aspiracje w kierunku zakładania własnych rodzin lub realizowania innych celów życiowych. Przejawiają również chęć zdobywania coraz większej wiedzy, która wyraża się w ich ciekawości świata, dlatego też orientacja na sukces nie jest dla nich tak ważna jak dla pozostałych uczniów. O niskiej podatności na wpływy ponowoczesności świadczy również fakt, że za czynniki najbardziej wyróżniające ich spośród innych osób, uznają przyjęty sposób myślenia oraz zasady, a także deklarują niewysoką umiejętność 
adaptacji do panujących warunków oraz rzadkie uleganie presji otoczenia.

Zmienna „miejsce zamieszkania” pozwala na stworzenie charakterystyk osób pochodzących ze wsi oraz dużych aglomeracji miejskich. Natomiast w przypadku mieszkańców małych oraz średnich miasteczek dane uzyskane na podstawie badań nie odznaczają się dostatecznym stopniem wiarygodności z tego względu, że liczba respondentów z tego typu miejscowości była zbyt mała, by móc uznać ją za reprezentatywną. Okazuje się, że młodzież wiejska często identyfikuje się z bardzo obiektywnymi i fundamentalnymi elementami konstrukcyjnymi tożsamości, jakie stanowią przynależność do gatunku ludzkiego, własna płeć czy rola społeczna lub rodzinna. Ponadto zwraca uwagę na własne zainteresowania oraz tożsamość narodową. Najważniejszą właściwością dla nich okazuje się być nie tylko charakter, ale również pełniona funkcja społeczna. Swoje plany przyszłościowe łączą głównie ze zdobyciem określonego zawodu, który prawdopodobnie postrzegany zostaje jako szansa na osiągnięcie niezależności finansowej. Część osób dopatruje się w nim także źródła prowadzącego do zajęcia wymarzonej pozycji społecznej, z czego wynika orientowanie się w kierunku sukcesu, za cenę którego są skłonne ponieść wiele wyrzeczeń oraz chęci poznawania otaczającego świata. Młodzi ludzie pochodzący z terenów wiejskich bardzo wyraźnie odczuwają szybkie tempo życia, które uważa się za typową cechę ponowoczesności. Odnoszą wrażenie natłoku zadań i obowiązków, przyczyniające się do pozostawania w permanentnym ruchu. Ponadto przejawiają tendencję do sprzecznych zachowań wyrażającą się w deklarowaniu niechęci do podporządkowywania się panującym schematom działania, którym jednak ulegają prezentując skłonność do przyjmowania postawy konsumpcyjnej. Za przyczynę takiego stanu rzeczy można uznać chęć funkcjonowania zgodnie z modą, która narzuca dążenie do pozyskiwania coraz większej ilości dóbr. Ciekawym spostrzeżeniem jest również fakt, że młodzież wiejska wyobraża sobie ponowoczesność w sposób bardziej negatywny niż jej miejscy rówieśnicy. Co więcej, kojarzy ją przede wszystkim z pojawianiem się zmian w zachowaniach ludzi i zauważa walkę toczoną $\mathrm{z}$ trwającym obecnie kryzysem.

Młodzież wielkomiejska zdecydowanie rzadziej identyfikuje się z właściwościami wymienianymi przez swoich rówieśników pochodzących ze wsi, częściej zwraca uwagę wyłącznie na własną tożsamość lokalną. Cechę uznaną przez nią za najważniejszą stanowi charakter, którego odpowiednie kształtowanie niejednokrotnie zostaje postrzegane jako główny obszar aspiracji przyszłościowych. Ponadto, do postaw częściej przez nią wybieranych można zaliczyć anonimowość oraz zdolność adaptowania się do istniejących warunków, która prawdopodobnie przyczynia się do większej skłonności spostrzegania świata w kategoriach pozytywnych. Wynikają one ze specyfiki życia w mieście, które wyróżnia się koniecznością funkcjonowania w tłumie ludzi, gwarze ruchu ulicznego oraz radzenia sobie z szybkim tempem egzystencji. Zachodzenie przytoczonych zjawisk 
potwierdza dążenie do poszukiwania wrażeń i nudzenie się wykonywaną czynnością. Młodzi ludzie pochodzący z wielkich aglomeracji miejskich przedstawiają się jako grupa bardzo tolerancyjna na odmienności, co również spowodowane jest przez przyzwyczajenie do różnorodności, a także wielokulturowości mieszkańców miast. Współczesne czasy definiuje głównie poprzez odniesienie do pojawiania się nowych światopoglądów i sposobów myślenia, które wpływają na orientowanie się społeczeństw na tworzenie wzajemnych powiązań i relacji o charakterze ponadnarodowym oraz poczucie zbiorowej odpowiedzialności. Jednak, pomimo pojawiających się pozytywnych określeń na temat ponowoczesności, przewidują jej zmierzenie ku samozagładzie.

Badana młodzież prezentuje bardzo bogaty i urozmaicony repertuar autoidentyfikacji, co dowodzi istnienia różnic występujących pomiędzy jej przedstawicielami. Dodatkowo potwierdza ich zdolność do przeprowadzenia świadomej autoanalizy, która stanowi podstawę tworzenia obrazu siebie. „Poprzez swoje interesy, aspiracje, cele, które przypisuje sobie, a więc na podstawie wyobrażenia o tym, kim jest i czego chce" (Szczepański, 1978: 32) jednostka kształtuje również swój stosunek do innych ludzi i świata. Taki stan rzeczy wynika przede wszystkim z jej prawa do wolności i dokonywania samodzielnych wyborów. Współczesna rzeczywistość wydaje się być przychylna odmiennościom i stwarza możliwość stawania się tym, kim pragniemy. Nie stawia wymogów prezentowania właściwości charakterystycznych dla wszystkich ludzi i posiadania z góry określonych cech, co z pewnością przyczynia się do coraz częstszego zrywania z zasadą monomitu ${ }^{4}$. Młodzież z całą pewnością korzysta z powstałych sposobności, jednak należy również zauważyć, że przejawia przymioty typowe dla czasów ponowoczesnych. W związku z czym przypuszcza się, że własną tożsamość kreuje na podstawie gamy dostępnych środków. Zostaje niejako uwodzona przez wszelkiego rodzaju zasoby, oparte przede wszystkim na konsumpcji (Melosik, Szkudlarek, 2010: 97).

Współczesna młodzież jest zmuszona do funkcjonowania w szybko zmieniającej się rzeczywistości, pozbawionej stabilnych znaczeń. Sprawia ona wrażenie nieprzychylnie ustosunkowanej do życia. Nastolatki borykają się z licznymi problemami. Ciągłe przeobrażenia gospodarcze stają się przyczyną „rozchwiania norm moralnych i postrzegania systemu normatywnego jako społecznie niepewnego" (Kluz, 2005: 13). Może to prowadzić do zagubienia i niemożliwości skrystalizowania swojej tożsamości oraz wypracowania hierarchii wartości. Rozwijająca się kultura konsumpcjonizmu zmusza niejako do przyjęcia swoich zasad funkcjonowania, mimo że niekoniecznie może cieszyć się uznaniem młodych jednostek (Kowalski, 2005: 17-19). Z jednej strony są one obciążone odnajdywaniem siebie i kształtowaniem

\footnotetext{
${ }^{4}$ Kategoria wprowadzona przez Jospeha Campbella w publikacji Bohater o tysiacu twarzy, Poznań 1997, Zysk i Ska, s. 283.
} 
swojego losu, z drugiej zaś muszą współgrać z życiem świata (Makaś, 2010: 197). Zostają zobowiązane do wykazywania się krytycyzmem myślenia, spontanicznością, twórczością, a jednocześnie skutecznością działania (Makaś, 2010: 201-202). Co więcej, cechy te nie mają być tylko przywilejem ich młodości, ale ciąży na nich obowiązek ich utrzymania przez całe życie. Wszelkie te umiejętności muszą pozyskać samodzielnie, ponieważ ich rodzice i wcześniejsze generacje nie opanowały ich $\mathrm{w}$ tak wysokim stopniu, jak jest to wymagane, w związku z czym nie są $\mathrm{w}$ stanie nauczyć ich swoich dzieci.

Okres młodzieńczości przepełniony jest licznymi skrajnościami. Z jednej strony stwarza ogromne możliwości w podejmowaniu decyzji, jednostka sama dokonuje wyboru, kim chciałaby zostać, kreuje swoje własne autorytety, dłuższy czas spędza w placówkach edukacyjnych, w związku z czym poszerza swoją wiedzę, posiada większy dostęp do informacji. Z drugiej zaś strony, adolescenci narażeni są na wiele niebezpieczeństw potęgowanych przez współczesną kulturę ryzyka (Beck, 2002) oraz narastającą przemoc. Sytuacja taka wymaga ogromnych umiejętności adaptacyjnych, wykształcenia mechanizmu szybkiego działania i odporności na stres. Jednak mimo tych trudności okazuje się, że młodzi ludzie wcale nie chcą być dorośli (Sińczuch, 2002: 165-182). Świat osób dojrzałych jawi się im jako „wstrętny, odpychający, a przynajmniej, pełen głupoty, dwulicowości, lekceważenia własnych obowiązków zawodowych, gry pozorów, świat zasługujący na pogardę, a przynajmniej na wszelkie próby dystansu" (Witkowski, 2007: 132-133). Czynniki te przyczyniają się do opóźnianiu momentu wchodzenia w dorosłość.

W obliczu niniejszych rozważań rodzi się pytanie: na jakich zasadach najlepiej tworzyć obraz własnej osoby w warunkach stworzonych przez obecne czasy? Bardzo słuszne wydaje się być stwierdzenie utrzymujące, że „niezależnie od tego, jakie czynniki zmienności weźmiemy pod uwagę, kierunek rozwoju człowieka, jego samorealizacji, zależeć będzie od integrowania w sobie tego, co trwałe w doświadczeniach przeszłości i otwarcia na to, co jako nowe i zmienne niesie rzeczywistość codziennych zdarzeń. A więc w sumie - wierność i otwartość. Na nich opiera się tożsamość" (Szewczyk, 2000: 45).

Badani adolescenci wykazują cechy charakterystyczne dla czasów współczesnych oraz w pewnym stopniu reprezentują właściwości typowe dla tożsamości ponowoczesnych, których koncepcje zostały sformułowane przez takich badaczy jak Zygmunt Bauman i Zbyszko Melosik. Pozwala im to nie tylko odnajdywać się we współczesnej rzeczywistości, ale również przyczynia się do sprawniejszego w nich funkcjonowania. W związku z czym niebezpodstawne wydaje się być twierdzenie Zofii Nałkowskiej zamieszczone w Granicy, utrzymujące, że „jest się takim jak miejsce, w którym się jest". Żadna jednostka, mimo najszczerszych chęci, nie jest $\mathrm{w}$ stanie konstruować swojego profilu autoidentyfikacyjnego $\mathrm{w}$ całkowitym oderwaniu od otaczającego ją świata. 
Nie oznacza to jednak, że należy bezkrytycznie przyjmować wszelkie płynące z niego wskazówki istotne dla tworzenia swojego „Ja”. Dlatego też młodzież powinna być odpowiednio wspierana w procesie poszukiwania własnych identyfikacji nie tylko przez najbliższe środowisko swojego życia, jakie stanowi rodzina, ale również przez szkołę, w której spędza znaczną część swojego czasu oraz otoczenie lokalne. Zaprezentowana charakterystyka tożsamości młodych ludzi składnia ku refleksji oscylującej wokół obszarów wymagających bliższej analizy. Jej celem absolutnie nie pozostaje krytyka ani stwierdzenie, że współczesna młodzież przejawia negatywnie ukształtowaną tożsamość, tylko wskazanie płaszczyzn potrzebujących większej troski wychowawczej i wyłonienie nowych tendencji rozwojowych, typowych dla budowania obrazu siebie. Młode jednostki obierają bowiem odpowiadający sobie kierunek identyfikacji, który, co ważniejsze, stanowi najlepszy z możliwych w obecnych warunkach ich życia.

Przede wszystkim należy zauważyć, że młodzież poprzez bardzo częste deklarowanie planów związanych $\mathrm{z}$ własną orientacją zawodową sygnalizuje ogromną potrzebę korzystania $\mathrm{z}$ poradnictwa związanego $\mathrm{z}$ tym obszarem. Wynika ona przede wszystkim $z$ obieranego przez nich celu, jaki stanowi zdobycie konkretnego zawodu. Tendencja taka z jednej strony, dowodzi wysokiego stopnia świadomości, związanej z przekonaniem, że praca jest jednym z głównych elementów naszej aktywności życiowej, z drugiej zaś wydaje się być niebezpieczna $\mathrm{z}$ tego względu, że współczesny rynek pracy wymaga wysokiego stopnia elastyczności i umiejętności nawet kilkakrotnego przekwalifikowywania się w ciągu wieku produkcyjnego. Ponadto, warto zachęcać młodych ludzi do głębszego analizowania własnej osobowości nie tylko w jej aspektach obiektywnych, które były najczęściej przez nich dostrzegane, ale także w kategoriach subiektywnych, zorientowanych na głębsze wnikanie w siebie (Szczepański, 1983: 131-178). Ciekawym spostrzeżeniem wydaje się być również fakt, że adolescenci bardzo rzadko odnoszą się do właściwości swojego organizmu, jego wyglądu, wieku. Zjawisko takie można interpretować jako czynienie z nich bardzo podstawowych kwestii, stanowiących niejako aksjomat ludzkiego istnienia, w związku z czym ze względu na swoją oczywistość zostają pomijane w rozważaniach na swój temat. Dlatego też warto byłoby zachęcić ich do wnikliwszego analizowania go i uświadomienia jego ogromnej roli w konturowaniu tożsamości (Szczepański, 1978: 33-34). Podobna sytuacja zachodzi w przypadku poczucia wyjątkowości oraz bycia sobą. Badani co prawda deklarują bardzo rzadkie udawanie kogoś, kim nie są, jednak równie rzadko podkreślają, że czują się sobą. Bardzo trudno uzyskać taką właściwość we współczesnych warunkach permanentnej zmiany, jednak „konieczność poczucia tożsamości oraz konieczność dążenia do utrzymania tożsamości są zjawiskami pochodnymi wartości osoby jako indywidualności jedynej i niepowtarzalnej. Jest po prostu ontologiczną cechą osoby, że nie może istnieć bez uświadomienia sobie własnej wartości" (Szczepański, 
1988: 106-107), w związku z czym powinno się również wzmacniać umiejętność krytycznego myślenia, która stanowi bardzo charakterystyczną właściwość okresu dojrzewania, jednak wydaje się być coraz bardziej zatracana przez obecną młodzież, prawdopodobnie poprzez nieustanny brak czasu, nadmiar obowiązków i wynikającą stąd konieczność szybkiego podejmowania decyzji. Natomiast dzięki krytycyzmowi nie przyjmowałaby wszystkich propozycji dyktowanych przez współczesność, tylko poddawała je wnikliwej analizie i badała, czy rzeczywiście są dobre dla niej. Dodatkowo, należy podnosić świadomość tego, że obecny świat, bez względu na swoje właściwości, stanowi środowisko naszego życia, dlatego też w wyniku wzajemnej współpracy powinno się troszczyć o jego lepszy byt. Warto także zauważyć, że pozytywnym zjawiskiem w obszarze identyfikacji młodych ludzi okazuje się fakt, że nadal istotną rolę odgrywa dla nich życie rodzinne oraz nie są zbyt intensywnie zorientowani na konsumpcję.

Wyniki badań wskazują na istnienie pewnego paradoksu myślowego wśród młodych ludzi, polegającego na tym, że oceniają świat w kategoriach bardzo negatywnych oraz wróżą jego bliską zagładę, jednak snują dalekosiężne i bardzo optymistyczne plany przyszłościowe oraz co ważniejsze, wszystkie z nich bazują na zasobach i możliwościach oferowanych przez ponowoczesność. Tendencję taką można wyjaśnić, odnosząc się do interesującego stwierdzenia Zdzisława Kosyrza, który utrzymuje, że postrzeganie współczesnego świata jako dualistycznego wcale nie oznacza sprzeczności w jego odbiorze, ale stanowi wynik głębokich przemyśleń, które w konsekwencji bazują na wniosku, że właściwości sprzeczne są ze sobą tak silnie powiązane, że stanowią swoje kontinuum (Kosyrz, 2012: 16-17). Ponadto młodzież słusznie ocenia ponowoczesność, która nie jest inna, jak właśnie pełna sprzeczności.

Niebywałym atutem wieku dojrzewania staje się „poczucie otwartości życia” (Kołakowski, 2000: 64), wyrażające się w nieograniczonej możliwości dokonywania wyborów, popełniania błędów, inaczej mówiąc - w życiu pełnym wolności. Właściwość ta przekłada się również na sferę poszukiwania własnych identyfikacji, które często wpływają na późniejsze losy jednostki. W związku z czym, mimo że proces ten $\mathrm{w}$ głównej mierze ma miejsce w najbardziej burzliwym okresie naszego życia, jakim jest pokwitanie, powinien być starannie przemyślany i otoczony wysokim zainteresowaniem nie tylko samej przeżywającej go osoby, ale również jej otoczenia. Zadanie to wydaje się być tym trudniejsze, że współcześnie odbywa się w bardzo skomplikowanych, a jednocześnie stwarzających wiele możliwości warunkach. W dobie ponowoczesności człowiek, udzielając sobie odpowiedzi na podstawowe pytanie egzystencjalne „Kim jestem?”, nie zastanawia się nad tym, kim musi lub powinien być albo kim być nie może, ponieważ będąc wolnym podmiotem własnych działań, oczywiście zachowując poszanowanie praw i godności innych ludzi - samodzielnie kreuje swoje własne „JA” w myśl indywidualnie i subiektywnie ułożonego planu. 
Świat wielości możliwości stanowi niezgłębioną tajemnicę nie tylko dla ludzi dojrzałych, ale przede wszystkim dla jednostek młodych, które przeżywając okres przejściowy pomiędzy dzieciństwem a dorosłością, są zobligowane do podejmowania samodzielnych i odpowiedzialnych decyzji, mających decydujący wpływ na ich dalsze życia. Dlatego też bardzo istotne jest to, by odpowiednio ukierunkowywać swoje działania w myśl indywidualnie skonstruowanego planu rozwojowego, wykorzystując optimum szans oferowanych przez współczesność.

\section{Literatura}

Bartnicka K. (1994). Dziecko w świetle pamiętników i powieści polskiego Oświecenia. (W:) Studia $z$ dziejów edukacji. Red. J. Miąso. Warszawa

Bauman Z. (1993). Ponowoczesne wzory osobowe. „Studia Socjologiczne” nr 2 (19)

Bauman Z. (1996). Etyka ponowoczesna. Warszawa

Bauman Z. (2000a). Globalizacja. I co z tego dla ludzi wynika. Warszawa

Bauman Z. (2000b). Ponowoczesność jako źródło cierpień. Warszawa

Bauman Z. (2005). Europa - niedokończona przygoda. Kraków

Bauman Z. (2007). Płynne życie. Kraków

Bauman Z. (2011). 44 listy ze świata płynnej nowoczesności. Kraków

Bąk T. (2008). Współczesne uwarunkowania kreacji subkultur młodzieżowych. Warszawa

Beck U. (2002). Społeczeństwo ryzyka. W drodze do innej nowoczesności. Warszawa

Brich A., Malim T. (2002). Psychologia rozwojowa w zarysie: od niemowlęctwa do dorosłości. Warszawa

Brzezińska A. (2007). Społeczna psychologia rozwoju. Warszawa

Campbell J. (1997). Bohater o tysiącu twarzy. Poznań

Cybal-Michalska A. (2006). Tożsamość młodzieży w perspektywie globalnego świata. Studium socjopedagogiczne. Poznań

Dziamski G. (1995). Ponowoczesna świadomość estetyczna. (W:) Trudna ponowoczesność. Rozmowy z Zygmuntem Baumanem, cz. I. Red. A. Zeidler-Janiszewska. Poznań

Eisenstadt N.S. (1996). Von Generation zu Generation. Altersgruppen und Sozialstruktur. (W:) Griese H.M. Socjologiczne teorie młodzieży. Kraków

Erikson E.H. (2004). Tożsamość a cykl życia. Poznań

Fiut I. (2004). Człowiek ponowoczesny. „Studia Humanistyczne/Akademia Górniczo-Hutnicza im. Stanisława Staszica" t. 2

Golka M. (2006). Czym bywa tożsamość? (W:) Człowiek i Społeczeństwo. Kłopoty z tożsamością. Red. M. Golka. T. XXVI. Poznań

Habermas J. (2000) Filozoficzny dyskurs nowoczesności. Kraków

Horney K. (2001). Nerwica a rozwój człowieka. Trudna droga do samorealizacji. Poznań

Huizinga J. (1967). Homo ludens. Zabawa jako źródło kultury. Warszawa

James W. (2002). Psychologia. Kurs skrócony. Warszawa

Kluz T. (2005). Problemy wieku adolescencji w okresie zmian społecznych. „Wychowanie Na Co Dzień" nr $1 / 2$

Kołakowski L. (2000). Mini wykłady o maxi sprawach, seria druga. Kraków 
Kosyrz Z. (2012). Oblicza tożsamości. Warszawa

Kowalski M. (2005). Wokół triady: młodzież - konsumpcja - wychowanie (refleksje). „Wychowanie Na Co Dzień" nr 1/2

Lyotard J.F. (1997). Kondycja ponowoczesna. Warszawa

MacDonald D. (2002). Kultura masowa. Kraków

Makaś A. (2010). Młodzież w czasach ryzyka. (W:) Młodzież w XXI wieku. Źródła wzrostu i kryzysów. Red. E. Jackowska, B. Kromolicka. Szczecin

Mannheim K. (1996). Das Problem der Generationen. (W:) Griese H.M. Socjologiczne teorie młodzieży. Kraków

Marcel G. (1960). Homo viator, Warszawa

Marciniak M. (2011). Orientacje konsumpcyjne młodzieży akademickiej. Perspektywa Baumanowska, t. 5. Kraków

Mead M. (1978). Kultura i tożsamość. Studium dystansu międzypokoleniowego. Warszawa

Melosik Z., Szkudlarek T. (2010). Kultura, tożsamość i edukacja. Migotanie znaczeń. Kraków

Okoń W. (2007). Nowy słownik pedagogiczny. Warszawa

Oleniacz M. (2005). Przeżywanie młodości. Obraz fenomenu w badaniach biograficznych. Kraków

Oleś P.K. (2011). Psychologia człowieka dorosłego, Ciagłość - zmiana - integracja. Warszawa

Pico della Mirandola G. (2010). Oratio de hominis dignitate = Mowa o godności człowieka. Warszawa

Psychologia dziecka. (1995). Red. R. Vasta, M.M. Haith, S.A. Miller. Warszawa

Schelski H. (1996). Die skeptische Generation. Eine Soziologie der Jugend. (W:) Griese H.M. Socjologiczne teorie młodzieży. Kraków

Sińczuch M. (2002). Wchodzenie $w$ dorosłość $w$ warunkach zmiany społecznej. Warszawa

Siwko M. (2006). Młodzież polska w integrującej się Europie. Koszalin

Smart B. (1998). Postmodernizm. Poznań

Szahaj A. (1995). Nadzieja w postnowoczesności. Poglądy Zygmunta Baumana na mapie stanowisk w kwestii oceny postmodernizmu. (W:) Trudna ponowoczesność. Rozmowy z Zygmuntem Baumanem, cz. I. Red. A. Zeidler-Janiszewska. Poznań

Szczepański J. (1978). Sprawy ludzkie. Warszawa

Szczepański J. (1983). Zapytaj samego siebie. Warszawa

Szczepański J. (1988). O indywidualności. Warszawa

Szewczyk W. (2000). O tożsamości osobowej, czyli jak być sobq wśród „ruchomych piasków”. (W:) Człowiek przełomu tysiąclecia. Problemy psychologiczne. Red. J. Makselon. Kraków

Trudna ponowoczesność. Rozmowy z Zygmuntem Baumanem, cz. I. (1995). Red. A. Zeidler-Janiszewska. Poznań

Trzebińska E. (1992). Z badań nad rozwojem i funkcjonowaniem tożsamości. „Przegląd Psychologiczny" t. XXXV, nr 2

Witkowski L. (2007). Edukacja wobec sporów o (po)nowoczesności, t. 1. Warszawa

Znaniecki F. (2001). Ludzie teraźniejsi a cywilizacja przyszłości. Warszawa 


\section{Self-Identifications of Contemporary Youth - A Contribution Towards The Debate on the Topic: Youth, Who Is That?}

\section{Summary}

Modern reality seems to be very hostile towards an individual due to its ambivalence, diversity, unpredictability and constant change. It has the strongest influence over young individuals, who are the most susceptible, due to the specifics of adolescence. This situation requires them not only to adapt easily to their environment but also to form adaptational mechanisms. One of the most important tasks a teenager faces is constructing his o hers identity constituting the foundation of "self”. It appears that similarly as the modern times it can't be straightforward, otherwise it becomes dysfunctional. At he same time it can't be too changeable and volatile i order not to cause the feeling of confusion anconstant uncertainty. It raises a question what should constitute an identity fit for out time? What values should the youths adopt in order to avoid the feeling of the desintegration of personality? It's unquestionable that founding one's auto identification becomes paramount for an individual, especialy a teenager. One of the argument supporting this claim is the fact, that the choice of certain personality orientations influences the efforts undertaken by an individual. Additionally forming a stable feeling of self allows those efforts to be consistent and allows to depend on some constant values in a situation of confusion. The author decided to conduct a study which resulted with answers given by teenagers to the basic existential questions, beeing the very foundation of human functioning: „who am I”, „who do I want to be”, „who can I be”. The results show that young people feel very comfortable in the surrounding reality. They identify with basic values falling both in the area of inter-and intra-psychic functioning of the unit. The field of identification can be found in categories as "beeing a human beeing”, own gender, one's personality traits and social roles. They can be classified as basic classification rules of human life, which is an indication that young people gravitate toward fundamental values. Their considerations about themselves are rarely about nationality, local comunity or religion, which shows that they don't share the values that were very important for older generations. It i also disturbing that youths rarely state that they "are themselves” or that they feel extraordinary. This situation is probably caused by the conditions of modern life, which due to the speed and numer of changes force changes to one's self, which in turn causes the lack of stability of own auto identification and the feeling of need to keep up with progress causes the lack of the feeling of extraordinariness. Another explanation might be the fact, that the question of "beeing themselves" is so obvious for young people that they don't feel the need to mention it. In the field of future orientation young people place their aspirations in proffesional career defined by a profession that they wish to undertake or by a position that they want to achieve. They think about changing their character, starting a family or continuing education less frequently. It shows a high level of understanding of the fact, that young individuals are forced to start professional activity in order to properly function in a society. Unfortunately the modern world is perceived by young people mostly in negative categories. They see its crisis, which may lead to its self destruction. It means that they wish to live in a reality diffrent from the one they live in right now. They developed excelent adaptational mechanisms which allowed them to adapt to current conditions. The modern world, despite all its shortcomings, offers many chances of self development. An individual has the right to choose the goods he or she wishes to make use of and the direction he or she wishes to develop in. The big advantage of modern times is the abandonment of strict rules of conduct, which 
allows developing ones self in any direction. Adolescence is a time for making choices and errors, because it's a time of searching for ones place in the world. It influences the sphere of self identification, which clarification often influences the future of an individual. Because of that even though this process takes place in the most turbulent period of our lives it should be carefuly thought over and given much care not only by the individual going throught it, but also by the people around. This task seems to be even more difficult because it takes place in a complicated environment, which also offers many possibilities. In a post-modern society a person answering the basic existential question ,who am I?" doesn't think about who he or she should or can be because beeing a free subject of action, with consideration of laws and dignity of other people, creates his or hers own self individually, with a subjectively composed plan. 